\title{
A review of Indigenous tourism in Latin America: reflections on an anthropological study of Guna tourism (Panama)
}

\section{Xerardo Pereiro}

To cite this article: Xerardo Pereiro (2016): A review of Indigenous tourism in Latin America: reflections on an anthropological study of Guna tourism (Panama), Journal of Sustainable Tourism

To link to this article: http://dx.doi.org/10.1080/09669582.2016.1189924

Published online: 31 May 2016.

Submit your article to this journal $\pi$

Q View related articles $\longleftarrow$

View Crossmark data \lceil 


\title{
A review of Indigenous tourism in Latin America: reflections on an anthropological study of Guna tourism (Panama)
}

\author{
Xerardo Pereiro \\ Departamento de Economia, Sociologia e Gestão (DESG), Escola de Ciências Humanas e Sociais (ECHS), Universidade \\ de Trás-os-Montes e Alto Douro (UTAD), Vila Real, Portugal
}

\begin{abstract}
Using ethnographic examples from long-term anthropological fieldwork with members of the Guna communities of Panama, undertaken between 2003 and 2013, this paper critically evaluates the effects of tourism on Indigenous communities in Latin America from a new theoretical perspective. It focuses on how some Latin American Indigenous groups are developing a new responsible way of producing tourism, exemplified by the Guna case. The Guna sustainable tourism model is an illuminating example of good practices in Indigenous tourism. Tourism is now not viewed as a threat for Indigenous groups but as an opportunity for the empowerment and development of communities, thanks to the establishment of a new link between the local and global in tourism arenas. The author's research findings reveal that the success of this sustainable and responsible Indigenous tourism model is supported by (1) the local control of resource access; (2) Indigenous resistance to external sociocultural control and the resultant refusal to accept predatory tourism models; and (3) the resilience, adaptation and cultural capital of Indigenous groups. The paper provides suggestions for a more appropriate Indigenous tourism development and for a responsible "cultural fine-tuning" of their identities in the global context in which tourism is now managed.
\end{abstract}

\section{ARTICLE HISTORY}

Received 13 August 2015

Accepted 10 May 2016

\section{KEYWORDS}

Indigenous tourism; Latin America; responsible tourism; tourism impacts; Guna Yala (Panama)

\section{Introduction}

Indigenous tourism has grown rapidly since the 1980s (Butler \& Hinch, 1996) due to the Western belief that Indigenous people are the preservers of the most genuine human values, and also retain a closer connection to a natural environment that the West considers at grave risk. That growth has given a boost to anthropological studies on Indigenous tourism. This paper focuses on a new understanding of Indigenous tourism as an academic concept, an attractive and marketable tourism product and an opportunity for the more autonomous development of Indigenous communities. We discuss what the social conditions to better benefit Indigenous people are, and reflect on tourism's potential to act as an internal Indigenous force, as the Guna case demonstrates, rather than an overwhelmingly external sociocultural force. Is Indigenous tourism a threat or an opportunity for development? In Latin America, what are the current trends in Indigenous tourism? What are the implications of Indigenous communities appropriating a part of the tourism products and services currently provided? Is it possible to create elsewhere the type of alternative and distinctly indigenous models of tourism development that have been observed in Latin America? 
The first part of this paper critically reviews the various conceptualizations of Indigenous tourism and the debates over the commodification of Indigenous cultures by tourism. The second part focuses in a reflexive and personal way on the methods used in this research. The third part analyses the effects of Indigenous tourism on receiving communities in Latin America. Finally, a case study of responsible tourism as practised in the Guna model of Indigenous tourism in Panama is presented. The paper concludes by suggesting that in Indigenous areas with no previous experience of tourism, the introduction of Indigenous tourism that develops slowly and leaves informed control with local people is less likely to have negative effects.

\section{Understanding Indigenous tourism}

Since the 1990s, Indigenous tourism has become an important field of investigation (Coronado, 2014; Mercer, 1995; Moscardo \& Pearce, 1999; Nielsen \& Wilson, 2012; Zeppel, 2007). The Canadian Tourism Commission (1997) compiled numerous bibliographical references for the Canadian case, and Zeppel (1999) did the same for Australia. A report by Kutzner, Maher, and Wright (2007) gathered 323 bibliographical references on Indigenous tourism, and, since its launch in 1981, the Bulletin of Latin American Research has published 41 articles related to Indigenous tourism.

In the 1990s, Indigenous tourism was defined as a set of first-hand experiences with Indigenous cultures (Harron \& Weiler, 1992), a form of cultural collection (Volkman, 1990) and also as a field of co-ethnic relations (Van den Berghe, 1980, 1994a), in which the tourist is attracted by cultures that exemplify the "other", the "different" and the ethnically "exotic", or represent the "native" as an object of tourist curiosity, and even as a form of culturally focused collecting almost akin to that of philatelists or art connoisseurs (Volkman, 1990). In this context, Valene Smith defined Indigenous tourism as the four "Hs" of habitat, heritage, history and handicrafts:

Indigenous tourism (...) is taken as that segment of the visitor industry which directly involves native peoples whose ethnicity is a tourist attraction (...) Indigenous tourism involves four interrelated elements: the geographic setting (habitat), the ethnographic traditions (heritage), the effects of acculturation (history), and the marketable handicrafts. (1996, pp. 283, 287)

Butler and Hinch favour a commercial Indigenous tourism in which culture remains under the Indigenous control of local communities, defining the term as consisting of:

Tourism activities in which Indigenous people are directly involved either through control and/or by having their culture serve as the essence of the attraction. $(1996$, p. 10)

From their perspective, in Indigenous tourism, the product rather than the form of travelling is different, with a commercial relationship being established between producers (locals, who are the possessors of native habitat, cultural heritage, social history and craftwork), and consumers (tourists who have an interest in such items). Similarly, Charles R. De Burlo has argued that Indigenous tourism refers to:

those activities which directly involve Indigenous peoples. In this type of tourism, the native groups are in control of enterprises which have Indigenous culture as a main attraction. (2000, p. 304)

Bruner (1995) adopts a more critical position: he states that the real lives of the natives are masked in order to make the search for Indigenous local colour more attractive to the tourist visitors, thus meeting more closely their expectations. Also, these very expectations - fuelled and formatted by tourist operators, the Internet and their own direct and virtual interactions - may diverge very significantly from the day-to-day experience of Indigenous people. Paradoxically, the traditional and Indigenous cultures described in the past by anthropologists, and now sought out by tourists, have often changed out of all recognition.

Within the framework of typological classifications, authors such as Valene Smith and Peter Van den Berghe conceptualized Indigenous tourism as different from cultural tourism (Pereiro, 2009). On 
the other hand, Richards (1996) affirms that Indigenous tourism can be a form of cultural tourism. Similarly, the World Tourism Organization has defined Indigenous tourism as a form of cultural tourism motivated by visitor interest in the ethnicity, traditions and lifestyle of Indigenous communities (UNWTO, 2003).

The distinction between Indigenous, ethnic and cultural tourism is rather blurred, but there are some key issues that are distinctive about Indigenous tourism. From our perspective, cultural tourism is a large academic category of tourist experiences that includes historical, ethnic, Indigenous and heritage products (see Pereiro, 2009). Ethnic tourism refers to the tourist experience with ethnic groups and their cultural roots (see Yang \& Wall, 2009), and Indigenous tourism is more centred on the attraction of Indigenous groups living in particular ecological niches.

From this latter perspective, Grünewald (2003) tries to define Indigenous tourism by reconciling the focus on the object of the tourist visit, i.e. the native, and the subject-centred perspective of tourist motivations. For Grünewald, Indigenous tourism is a metaphor in which a social movement constructs a quite specific Indigenous ethnicity so as to display it through tourism. Here, echoing Comaroff $(1992,2009)$, Indigenous ethnicity is socially constructed - a sort of do-it-yourself project, modelled (albeit asymmetrically) both by local culture and the global market.

More recently, a collection of studies on Indigenous tourism edited by Chris Ryan and Michel Aiken has had a huge impact on tourism research related to anthropology and other social sciences (2005). Though they bring together case studies from Oceania, East Asia, Canada and Scandinavia, examples from Latin America or from Indigenous authors are missing. Nonetheless, the theoretical perspectives concerning Indigenous tourism are innovative. In the introductory chapter, Ryan affirms that tourism contributes to the creation of stereotyped images of Indigenous villages (2005a, pp. $1-15)$ and, along the same lines, Ryan and Huyton $(2005$, p. 51) assert that for visitors to Indigenous communities the interactive experience is not as important as the purchase of arts and crafts.

In his analysis of the Indigenous tourism product, Ryan (2005b, p. 69) goes on to emphasize the paradox that tourism, in fulfilling its function of satisfying the desire for new economic opportunities for Indigenous areas, clashes with the effort of natives to protect their culture against commodification. Indeed, the commodification of Indigenous culture seems to be inevitable if the main objective is to make a profit from tourism. From our own standpoint, the basic question is whether tourism should establish ethical limits, or, as the conclusions to the above-mentioned work asks, whether loss of traditions can be avoided while at the same allowing local communities to profit from tourism activity. In essence, Ryan and Aicken (2005) and their collaborators analyse how Indigenous groups create and recreate their identities through tourism, while recognizing that "Indigenousness" is a key factor in tourism differentiation in the context of globalization.

This reconstruction of Indigenous identity to satisfy tourist expectations had already been observed and studied by several anthropologists (Comaroff \& Comaroff, 2009; Coronado, 2014; Grünewald, 2003; MacCannell, 1984, 1992; Vermeulen \& Govers, 2003). This process, which has led to the promotion and merchandising of Indigenous culture, transferring local identities and places onto the global tourist market, while it can result in the reinvention, recreation and preservation of Indigenous attributes by the natives, usually advances to the detriment of their privacy and may cause them a sense of invasion and threat. It is, therefore, undesirable for the term "Indigenous" to be applied as an absolute classification, but rather as a category that is malleable, flexible, dynamic and strategic, and subject to constant negotiations and renegotiations. Basically, Indigeneity can be defined as one of the ways in which differences between human groups in contact are socially organized (cf. Barth, 1969, 2003), thereby constituting not only a generally symbolic frontier between groups in contact (rather than implying cultural content that is strictly different), but also a third party or self-ascription or classification. Thus Indigeneity is a means of social identification based on a shared belief in and a consciousness of difference, and of common interests, lineage and history (Vermeulen \& Govers, 2003, pp. 11-12).

However, Indigeneity can also take the form of a narrative, particularly if it is deployed for the political expression of identities that are, in fact, a permanent work-in-progress. Indigenous identity 
promoted by Indigenous people is also reconstructed by tourism. This happens partly because of what Renato Rosaldo defined as "imperialist nostalgia", a perspective which makes colonial and neocolonial domination seem innocent and pure (1989). Imperialist nostalgia is inspired by western colonizers' regret over what has been destroyed in the past as the way of life of Indigenous communities were altered. Western tourists still feel guilty over their ancestors' actions; this often translates into an impossible yearning for things to be as they were before, and a failure to recognize that the reversion to the past is merely apparent, with Indigenous areas transformed into zoos, complete with all their autochthonous fauna frozen in time.

From a similar perspective, researchers like Dennison Nash (1977) or Duccio Canestrini (2009) have interpreted all tourism as a form of imperialism and neo-colonialism, a view that can be easily extended to Indigenous tourism. In line with this critical view, Johnston (2006) has pointed out that ecotourism in Indigenous areas is a tourist practice that allows Western middle classes to salve their feeling that they, too, have lost their own cultural and natural heritage. Born in the 1980s, ecotourism was linked to the sustainability trend, then, in the following decade, it appeared as a popular alternative to economically destructive exploitation. While accepting that ecotourism, which represented $5 \%$ volume of 2006 international tourism, is a relatively benign form of tourism, because it supports Indigenous cultures and creates spiritual connections with nature, Johnston nevertheless argues that ecotourism in Indigenous contexts causes a collision between environment interests and those of multinational companies and Indigenous communities (2006). The results of this conflict include a loss of the rights of the natives, the conversion of individuals and Indigenous communities into goods, the destruction of cultural identity and heritage, and the continuation of colonial policies and practices. In comparison with the point of view expressed in the studies collected by Ryan and Aicken (2005), in which the positions of researcher, designer of tourism products and manager of change all appear to coincide, Johnston is very critical of the commodification of Indigenous culture and its environment. She does not regard tourism as an activity that Indigenous communities are inevitably obliged to pursue, as Ryan and Aicken seem to suggest. On the contrary, Johnston asks if native sacredness and spirituality have to be sold through tourism.

The geographer Claudia Notzke (2006) compares alternative visions of the relative threats and opportunities of Indigenous tourism, using case studies from Latin America, Africa, Asia, Australia, Canada and even Europe. She points out that there is a political tension between the sacred and the profane in Indigenous tourism contexts, and between the native and visitor needs with regard to territorial appropriation. Her perspective, while more relativistic than that of Ryan and Aicken (2005), Notzke's overall perspective is more painstaking than that of Johnston (2006), since she scrutinizes the overall balance of positive and negative effects of Indigenous tourism on Indigenous communities in an attempt to see how the former may be maximized and the latter minimized.

In a more recent text on Indigenous Māori tourism, Thompson-Carr (2013) echoes Ryan and Aicken's reading. In New Zealand society, Māori are well integrated and have controlled their own tourism since the mid-1970s, when an intense cultural revitalization through tourism began, largely as a result of self-empowerment, pressure exercised on the government, and the resulting return of ancestral lands and an embracing of conservation measures. Their "eco-cultural" tourism (i.e. the interpretation of cultural values in natural contexts) attracts significant international tourism flows to Māori communities such as the town of Rotorua, where there are functioning village sites, a geothermal park, artisan centres and cultural events that include performances of the iconic "haka".

Nowadays, this debate over the negative or positive effects of the commodification of Indigenous cultures by tourism (revitalization, recreation, reinvention, etc.) has become more complex and requires a more in-depth interpretation. On the one hand, Indigenous people now consciously build differentiation into their tourism projects; on the other, Indigenous tourism has grown in a more responsible way, as a more community-based, participative, sustainable, ethical and ecological initiative (cf. Pereiro, Martínez, Ventocilla, De León, \& Del Valle, 2012). Far from being exclusively rural, new niches of Indigenous tourism have appeared (Pereiro et al., 2012), including large cities that have attracted Indigenous migration. Thus, Indigenous tourism not only delivers good value for money 
(Comaroff \& Comaroff, 2009, p. 30), but also provides a new way of constructing Indigenous sociocultural identities that are both resilient and adaptive to new times and new challenges.

From our point of view, Indigenous tourism is a logical extension of the changes that the tourist industry as a whole has been obliged to negotiate (such as Post-Fordist forms of economic organization, more individualized consumption patterns and Indigenous ethnicity of the statement). The object (and increasingly the subject) of Indigenous tourism consists of a group of culturally differentiated people who lived and occupied territories before the existence of the nation state (Saarinen, 2013, p. 221). Its development has been fuelled by the economic interests of Indigenous communities, and their use of collective identity as a means of self-organization, thereby contributing to their survival, reproduction and/or adaptation. Indigenous tourism constitutes both a successful start and a challenging future for the communities involved, since the self-management of Indigenous cultural identities can be problematic and, for this reason, a careful and critical examination of the content and development of this process is urgently required.

And what are the new horizons of Indigenous tourism as a product and a new form of more responsible tourism? Tourism is a powerful force for intercultural contact and creates a new framework of intercultural relations. By transcending frontiers, tourism challenges and altering pre-existing and preconceived images, reinforcing them and/or substituting them with new ones; as such, the experience and the process contribute both to the redefinition of cultural limits and to the creation of new cultural forms that are susceptible to commodification (Hernández Ramírez, 2006).

Different geopolitical constructions of Indigenous tourism in Central and South American countries, e.g. Guatemala, Panama, Mexico, Peru, Bolivia and Brazil, have skewed the development of Indigenous tourism towards international tourists attracted by Indigenous exoticism, often without involving the local communities (Pereiro, 2015). The perverse result is that the majority of the national population may have come to perceive Indigenous communities as being poor and inferior, symbolizing a degree of national backwardness, and almost constituting a cause for shame. In reaction to this, new forms of Indigenous tourism have emerged, belonging to the category of sustainable, responsible and alternative tourism, and have been undertaken in tourism development projects aimed at fighting poverty. Such projects have often been carried out in a framework of international cooperation (Gascón, 2009) on the basis of the Pro-Poor Tourism and the ST-EP (Sustainable Tourism Eliminating Poverty) strategies of the UNWTO. However, these projects have not always met with success (Gascón, 2009). Indigenous tourism will benefit from being more and more integrated into this kind of local social movements and alter-globalist tourism (see the debates on the Portalegre Social Forum of 2002 on www.ivt-rj.net/destaques/forum/index.htm).

An alternative Indigenous tourism could be more consistent with natural, social and community values that permit hosts and guests alike to interact positively and to enjoy valuable shared experiences (cf. Smith \& Eadington, 1992, p. 3). According to Barretto, Indigenous tourism is an alternative to traditional tourism sea, sun and sand products, a quite particular form of cultural tourism in which "the main attraction is the way of living of certain human groups, differentiated by race, religion, origin and other common characteristics" (Barretto, 2005, p. 40). So, the Indigenous groups use their ethnic differential as a tourist attraction. According to Barretto, there are two ways of developing Indigenous tourism:

(1) There are Indigenous tourisms that are born of purely commercial interests that reduce tourism to a business opportunity; they are typically non-participatory and unplanned, without the expressed consent of the community and conducive to the creation of human zoos.

(2) There are Indigenous tourisms that are the result of community-based cultural revitalization and Indigenous identity affirmation projects. Here, the self-determination of human groups allows tourists to selectively access some elements of Indigenous culture; key elements in its development are consultation, building sensitivity into public policies and establishing appropriate regulatory measures (Barretto, 2005, pp. 50-51). 
While this second form meets the requirements of community tourism, we cannot neglect the economic interests that often motivate a community and the ways in which the power of collective identity can help to achieve success. In this way, tourism can be "a business" or "the business" for an Indigenous people: in some cases, it can function mainly as an opportunity for survival; in others, it can provide the basis for defending and affirming Indigenous values and practices. In some cases, it will offer the promise of both outcomes, but in all cases, it poses difficult management challenges to all the protagonists. From our own perspective, the argument of Barretto (2005), while highly critical, is also reductionist, because Indigenous tourism development occurs along a spectrum rather than as a dichotomy, as can be observed in the discussion of the Latin American experiences of Indigenous tourism and their diversity which follows.

\section{Research methods}

In our work with Guna Indigenous tourism (Panama), a primarily anthropological approach was adopted which served to view responsible tourism as an alternative to conventional tourism development (cf. Pereiro, 2010; Pereiro et al., 2012). Anthropological fieldwork was carried out in Guna Yala and elsewhere from 2003 to 2013 using both participant observation and rigorous visual and documentary research. Our main contribution to the subject consists of a thorough systematic study of the diverse kinds of tourism and tourists to be found in Guna Yala (Panosso Netto, 2011). While the anthropological research was rooted in intellectual concerns and personal options, it also corresponded to concrete biographical trajectories, in the sense that the researcher's background affects the research problems he or she sees and the dynamics experienced as a researcher (cf. Phillimore \& Goodson, 2004; Ritchie, Burns, \& Palmer, 2005; Smith, 1999).

I met the Guna anthropologist Cebaldo de León Inawinapi in 2000, where he was lecturing and participating in seminars at the University of Trás-os-Montes and Alto Douro (UTAD) in Portugal. He later encouraged me to prepare a research project about ethnic tourism among the Guna of Panama, a theme neglected since the 1970s. The initial question that guided the design of research project was the extent to which tourism could act as a lever for social and cultural changes in an Indigenous group that seemed to be politically controlling its own process of tourism development. Moreover, Cebaldo de León's suggestion that I embark on a project outside Europe, an attractive idea, provided the opportunity to personally experience similarities and differences between an "anthropology conducted in one's own backyard" (which grosso modo had been the nature of my earlier research experiences) and an "anthropology in someone else's". I believed that leaving Europe would enrich my reflection and awareness of diversity and otherness by inducing a cultural shock that I considered both inevitable and necessary. Other reasons to advance with the project were:

(1) Cebaldo de León would be a sympathetic "gatekeeper" in the field during the project as, in any mediation between the researcher and the Gunas, he would facilitate acquiring research permission, establishing contacts with people and institutions, finding accommodation, etc., thus shortening the integration period and enabling better communication with the Gunas.

(2) Our mutual knowledge of Spanish (a second tongue for both parties) as a bridging language for the field work. The Gunas have their own language, but many also have some Spanish and English.

(3) The relative geographical proximity of Europe, approximately 11 hours by air to Panama.

(4) The romanticism attached to Guna resistance against the dominating powers (especially interesting to an anthropologist of Galician origin).

(5) Professional and personal support in the "adventure" of reorienting our research interests in a completely different research location.

(6) The personal interest in undertaking an ethnography of the tourism system in a geopolitically peripheral context. 
In addition to myself, Cebaldo de León and Ana Rita Lopes were members of the research team, which began work on Guna tourism in 2003, in a project in which many Gunas were both members of the team and collaborating with it. After a bibliographical review and resolution of practical issues, we made an exploratory visit to key areas. Having made field contacts, we sought permission from the highest Guna authorities, represented in the Guna General Congress (GGC), to undertake our project.

In 2004, Ana Rita Lopes undertook anthropologist fieldwork on the impacts of cruise boat tourism on the island of Gardi Suitupu. I studied the images that the tourism system had created of the Indigenous Gunas and their political behaviour, visited tourism projects, and conducted exploratory interviews and debates with Guna tourism entrepreneurs. In 2005, Cebaldo Inawinapi analysed the environmental impacts of tourism in Guna Yala, establishing contacts with communities and researching their perceptions of tourism. During 2006, we studied the supply of tourism products and services in Guna Yala and conducted interviews with local investors and stakeholders associated with 25 new small hotel projects. We participated in debates with the Guna Tourist Entrepreneurs' Association and the Tourism Commission of the GGC; we consulted Guna specialists, and collected documental and statistical material.

In 2007, the Catalan anthropologist Mónica Martinez Mauri, who had already carried out intensive field work in Guna Yala, joined the research team, allowing us to enlarge the units of analysis and areas explored. We organized further debates with Guna tourism entrepreneurs, and conducted interviews with politicians and tourism guides.

From 2008, the biologist Jorge Ventocilla Cuadros joined the research team, as did the Guna tourism scholar Yadixa del Valle, strengthening the interdisciplinary nature of the research.

Fieldwork was pursued from 2008 to 2013 in collaboration with Indigenous Gunas to research in depth the effects of tourism both on Indigenous communities and on tourists. This longitudinal, dialogical and collaborative research adopted a predominantly qualitative and inductive methodology (Phillimore \& Goodson, 2004), generating much new material. Significant value was added by co-creating knowledge with the Gunas. We confirmed the importance of Guna self-management in tourism development and the political control they exercise over their resources. Thus Guna communities are not only objects of other people's tourism but had also become protagonists and subjects of their own development strategy, creating a more sustainable and responsible model of Indigenous tourism.

\section{The effects of Indigenous tourism: Latin American perspectives}

This section analyses the power relations that characterize Indigenous tourism elsewhere in Latin America, and its complex manifestations. It sets our work with the Guna of Panama in the context of Latin America's Spanish language life and politics, and its market opportunities and limitations.

In the international literature on Indigenous tourism, much of the research draws on case studies and experiences from Africa, Asia, Canada, New Zealand, Australia and the United States, and comparatively little from Latin America (cf. Chang-Vargas, 2013; Lumsdon \& Swift, 2001; Osorio \& Rozo, 2013; Pereiro, 2013; Pereiro \& De León, 2007; Pereiro \& De León, 2014; Pereiro et al., 2012; Weaver, 2010; Wilson, 2008; Yang \& Wall, 2009, pp. 560-561). This situation has emerged because (1) English is the hegemonic language of tourism studies research, with publications in the predominant Latin American languages (Spanish and Portuguese) having had less impact on international debates (Mowforth, Charlton, \& Munt, 2008); (2) the comparatively recent development of Indigenous tourism in Latin America; and (3) the postcolonial motivation of many researchers - driven by nostalgia and/ or the pragmatics of ostensible familiarity - to work in their former colonies.

We must first of all recognize that the structure, dynamics and constraints of Indigenous tourism differ from one Latin American country to another. These national differences have influenced the differential development of Indigenous tourism as a product. Examples from three nations readily illustrate the diverse structuring of Indigenous tourism. Ecuador (Cavaco, 2011; Ruiz, Hernández, 
Coca, Cantero, \& Del Campo, 2008) has about 60 Indigenous communities providing tourism. Brazil has 305 Indigenous groups and 274 Indigenous languages (2010 Census); it has 672 demarcated Indigenous territories (with a further 115 cases being inventoried and researched), covering around $13 \%$ of Brazilian territory, about half of which offer Indigenous tourism experiences (Chaves, 2012). In Bolivia, 314 of its 327 Indigenous municipalities (96\%) have identified tourism as a priority for development (Zorn \& Farthing, 2007, p. 673).

If we analyse the research literature on Indigenous tourism in Latin America, there are three types of interpretative analysis concerning their consequences for Indigenous communities, reflecting (1) a positive or optimistic view of tourism, (2) a negative or critical view of tourism, and (3) a vision of creative adaptation to the changes brought about by tourism.

\section{The optimistic vision}

From the 1990s onwards, many authors have displayed an optimistic outlook on Indigenous tourism, affirming that it can promote cultural creativity, revitalize the arts and produce a platform for a more positive presentation of Indigenous communities. When analysing the positive effects of Indigenous tourism in Latin America, researchers place particular emphasis on the creation of tourist opportunities to meet people from different cultures and to engage in cultural exchange, thereby stimulating handcraft production (Getino, 1991). By visiting Indigenous communities, tourists gain respect for the local population, who in turn gain self-respect and the empowerment necessary to revitalize and maintain their language and/or traditions, thereby generating economic benefits that can mitigate the extreme poverty suffered by many of them (Mastny, 2003).

Typical representatives of this positive vision are Ingles (2002) in his case study of the Peruvian Amazon, Maldonado (2006) in his research on the redturs-web (see http://www.redturs.org), Espinosa (2010) in his publication on the Saraguro Rikuy community tourism web in Ecuador (see http://www. turismosaraguro.com), Chernela (2011) in his work on Guna ecotourism, and Morales and Marías (2007) in their analysis of the Mundo Maya-project, a Central American initiative for tourism cooperation in which Mexico, Guatemala, Belize, El Salvador and Honduras participate. In the latter project, native women make blouses and other textile products decorated with Indigenous motifs, and cultivate corn and chilli pepper for sale to the tourist visitors.

The cases of the Cofan of the Peruvian Amazon and the Ecuadorian Huaorani described by Mastny (2003) are particularly interesting from the standpoint of the Indigenous management of tourist visits, an achievement that remains exceptional. Indigenous groups have actively organized their tourism, and created accommodation units and handicrafts shops, thereby generating US\$500 of additional annual income per person. The Huaorani are developing community tourism, in which the earnings are equitably distributed, generating incomes twice as high as those of local oil company workers. Visitor groups are only received for periods of two to six days a month, as the Huaorani fear that more extended, intensive and intrusive tourism could destroy the hunting and farming on which their lives primarily depend. They guide their guests through the rain forest and, besides demonstrating craft techniques, pass on their ethno-botanical knowledge. Throughout the initiative, they have been advised by a tour operator, Tropical Ecological Adventures, a firm experienced in working with Indigenous communities, and whose Huaorani initiative won the 1998 award for best ecotourism project at the Berlin Tourism Exhibition (Blangy, 1999).

Another striking example is the Wanamei Expeditions travel agency (with its head office in Cuzco), jointly owned by eight Indigenous Amazon rainforest communities. It organizes responsible tourist tours through the traditional territories of the Harakmbut, Yine and Matsiguenga, via the Madre de Dios River (see http://www.ecoturismowanamei.com/main.php). In Capirona (Ecuador), a Quichua Indigenous community developed a model of tourism based on community ecotourism since 1989 (Colvin, 1994; Falconí \& Ponce, 2007). The community consists of 113 people and the project receives mainly European visitors interested not only in its culture and biodiversity, but also in experiencing a unique adventure in the Amazon. 
The community of Capirona is integrated into the Indigenous Community Network of the Upper Napo for Intercultural Exchange and Ecotourism (RICANCIE) that has been developing community ecotourism in nine Quichua communities since 1993, implementing organized tourism as a counterpart to what the above-mentioned authors refer to as "aggressive tourism" (see http://ricancie.native web.org/html/quienes.html). Unlike Capirona, a nearby community of Ongota, formed by 156 Quichua people, has opted for a model of development with direct access to modernization, working as employees in a mine and depending more on neighbouring small town of Tena, 45 minutes away by bus. The result has been major exclusion and inequality, and problems with its natural resources exemplified by the growing pollution of the local river.

In summary, according to this optimist view, tourism revitalizes social organization of Indigenous communities, provides them with new sources of economic and social prosperity, and opens up their communities to a world eager for contact with unique cultural identities.

\section{The critical vision}

A second category of researchers is more critical with regard to the effects of tourism on Indigenous populations (Cañada, 2010; Coronado, 2014; Gascón \& Cañada, 2005; Gascón Gutiérrez, 2005; Vigna, 2006). Some issues of the Cultural Survival Quarterly Magazine in 1982 and 1990 (see http://www.cul turalsurvival.org) had already serve a first warning by highlighting the negative consequences of tourism for Indigenous groups. A significant and enduring foundation stone for this vision was provided by the work of the anthropologist Pierre Van den Berghe (1994b), who analysed the changes produced by tourism in San Cristobal (Chiapas, Mexico). While in the 1960s the community received only a few backpackers, by the 1980s it was overwhelmed by hundreds of tourists in search of the "ethnically exotic", the "untouched", "primitive" and "authentic", a trend that generated radical alterations in Indigenous ways of living. Van den Berghe characterizes Indigenous tourism - which he regards as synonymous with ethnic tourism - as "the last expansion wave [to be felt by ...] the remote periphery of the world system" (Van den Berghe, 1994b, p. 10), with tourism characterized as a form of Western reconquest, and foreign tourists as the new conquistadores.

One of the most critical and accurate analysts of tourism developments in Latin America is Ernest Cañada (2010), who argues that it is necessary to question the official discourse that attributes to tourism a pre-eminent role in poverty reduction, ostensibly via employment creation and the incorporation of local suppliers into the tourism supply chain. The economic significance of tourism has grown since the 1980s agricultural crisis in Latin America, but this trend has implanted an "unsustainable tourist model" resulting in what he calls "tourism without development" and (Cañada, 2010, p. 12). As governments have been unable to exert any appreciable influence on the key actors in tourism development - the private sector in general and foreign capital in particular - investments have been concentrated in destinations that correspond to the "sun, sea and sand" model, leading to the creation of new coastal resorts by big international chains. The profits from all-inclusive packages, cruise ship arrivals and residential real estate tourism have generated few of the expected direct positive local effects, and the indirect effects of the model on Indigenous peoples have barely begun to be analysed.

Another example of bad practice is the case of Cancun in the region of Quintana Roo (Mexico), where tourism development has caused the de-characterization of the population of Mayan origin, involving the loss of their language, traditional mode of dress and sociocultural space. Mass tourism and its typical consumption culture have provoked the displacement of $65 \%$ of the Mayan population (Arnaizburne, 1996), the destruction of communal property, the consolidation of private property as well as the increase of social inequalities (Pi-Sunyer, Brooke, \& Daltabuit, 2001). Quintana Roo's story inspired the work on "The Just Destination" (Camargo \& Jamal, 2014), which explores ethical and sustainable tourism as a way forward for Indigenous peoples. 


\section{The adaptive vision}

Tourism brings good and bad things, but for the bad ones there is a remedy. (Esterbino, "Saila" or Chief of Armila, Guna Yala, Panama, 11-01-2010, quote recorded by the author)

The third perspective reconciles the two preceding opposite visions by stating that while tourism can bring about positive and negative effects, it also pushes communities to readjust to the changes and challenges in a creative way (Pérez Galán, 2011). From this point of view, instead of Indigenous tourism being reduced to a simple derivative of cultural tourism which allows the further diversification of tourism supply, it can be developed into an alternative, more reflexive form of ethical and educational tourism. The realization of this type of tourism will only be possible if it is undertaken in a planned way (Butler \& Hinch, 1996), with all its dimensions (speed, resources and empowerment) controlled by the natives themselves (Bricker, 2001; Gibson, Pratt, \& Movono, 2012; Simpson, 2008). This is what some authors call socially responsible tourism (Goodwin, 2011), or community-based tourism with a high degree of self-consciousness (Gascón, 2013; Rodríguez Miranda, 2011).

The work of the Brazilian anthropologist Grunewald (2001a, 2001b) provides a representative example of this third way. The Pataxó natives of the north-east of Brazil have used tourism to develop higher status, greater community cohesion and new cultural skills for themselves. They have proven themselves to be creative, adaptive and inventive with respect to their own culture as shown in the documentary by Zoettl (2010) on the Pataxó of the Coroa Vermelha community.

Another example of the adaptive vision is the study by Elisabeth Kirtsoglou and Dimitrios Theodossoupoulos (2004) of the Garifuna in Roatán, an island community in the Honduran Caribbean that receives approximately 100,000 , mainly American, tourists a year, who arrive by plane and cruise ship. The Garifuna realized that they benefitted too little from tourism and wanted to take control of not only the economic benefits, but also the way in which their culture was (re)presented. Having bent the situation to their will, the Garifuna now value tourism highly, not only because of the economic profits, but also the recognition of their cultural identity, heritage and property, and the freedom they now have to present themselves to the tourists without external mediation. This case proves that advantages for the local population are bigger if the natives themselves directly manage and control tourism development (Chambers, 2000, 2005).

Our own fieldwork on Indigenous tourism among the Guna communities also provides a clear example of this perspective (Pereiro \& De León, 2007; Pereiro et al., 2012). The research shows that tourism can act as a double-edged sword producing different types of effects. However, if it is politically controlled by the Indigenous population, the tourism system permits a better distribution of the benefits to be generated, the negative effects to be diminished or softened, and local communities to develop creative adaptability to shifting local-global relations and positive ethnic self-awareness. In this way, the quasi-monopoly of tourism development achieved by the Gunas is a part of their strategy of survival and cultural adaptation. Far from being passive and indifferent, the Gunas use tourism as a tool to achieve aims that are economic (poverty reduction and increasing economic benefits), political (reclaiming territorial autonomy), environmental (preservation of their environment) and sociocultural (increasing their cultural rights and collective self-esteem).

\section{Indigenous tourism self-managed by the Gunas}

The Gunas of Panama are an Indigenous group consisting of approximately 80,000 people living mainly in the comarca (an autonomous territory) of Guna Yala (the Caribbean coast) and in the cities of Panamá (cf. Howe, 1998, 2009; Pereiro et al., 2012). They have political and territorial autonomy within the Republic of Panama. Traditionally, they made their living by fishing, farming and hunting (cf. Howe, 2009), but over the last decades, tourism has emerged as the main opportunity of development. The Gunas are currently experiencing substantial changes and many are becoming turistores (travel and tourism agents). In our research, we analysed the role of tourism in the development of 
the Indigenous Guna communities, studying its impact on society, culture, economy and environment (Pereiro \& De León, 2007; Pereiro et al, 2012).

Guna Yala (San Blas in Spanish and Tule Nega in the ancient Guna language) is the present-day Guna name for the territory that stretches for a little over $225 \mathrm{~km}$ along the Caribbean coast of Panama as far as the frontier with Colombia. The Guna Yala population of Panama lives on 40 islands and in 12 small coastal villages, as well as in the urban centres of the country (Pereiro et al., 2012). The Gunas are one of the seven Indigenous groups of Panama, along with the Ngöbe, Emberá, Wounáan, Buglé, Naso and Bri-Bri, who together constitute a total of about $10 \%$ of the Panamanian population. Today, the Gunas dwell in the comarcas (autonomous territories) of Guna Yala, Wargandi and Madungandi, and also in the urban centres of Panama and in Colombia.

The life of the Guna people was markedly affected by the revolution in February 1925 (Howe, $1998,2009)$, on account of which, along with their constant political efforts, the Gunas were able to forge a political and territorial autonomy recognized by the state of Panama (Law 16 of 19-02-1953) and by international and even multinational cooperation agencies. They are governed by the GGC, the supreme authority of the comarca of Guna Yala. For some decades, the Gunas have been experiencing a process of sociocultural change wrought by an intensification of tourism (increased tourist activity) and urbanization (migration to urban centres) in the context of social, cultural, political and economic globalization.

Although in the 1990s the Gunas still viewed all tourism as a threat, over later decades this way of thinking has matured inasmuch as sustainable and responsible forms of tourism are now beginning to be considered a more attractive development opportunity (Pereiro et al., 2012). In fact, the process is regarded as unstoppable, as many of the communities that previously did not regard tourism as a development key have already begun to build the infrastructure needed for tourist activity. From El Porvenir, the comarca's capital in the extreme west, to the frontier with Colombia, 50 small hotels were already operating in 2016, managed and controlled exclusively by Gunas, catering for an inflow of tourism from the United States, Europe, Latin America and the Colombian coast.

In 1996, Guna authorities created the Statute of Guna Tourism (see www.congresogeneralkuna. org), an effort by the Guna people to control tourism and to define their tourist relationship with outsiders (Pereiro et al., 2012; Snow, 2001). Article 12 defines the carrying capacity of the islands, in terms of accommodation (40 for an inhabited community and 60 for an island without a settled population). The Statute of Guna Tourism provides a way of limiting the cultural change and defining Guna tourism's sustainability in a social, economic and environmental sense. Article 26 stipulates that all tourist guides must be Gunas, and Article 29 limits to 200, the number of yachts and other sailing boats permitted in Guna Yala's waters at any time. Article 38 states that "All individuals or legally constituted bodies from beyond the borders of the territory of Guna Yala that develop tourist activities inside Guna Yala must pay $10 \%$ of their tourist services revenues" as a tax. Contraventions are punishable by fines ranging from US\$100 to US\$1000, according to the seriousness of the case, as defined by the Board of Directors of the GGC.

The Guna model of tourism has been classified as ethnic tourism, eco-ethnotourism, eco-agrotourism, community tourism or, more appropriately from our own perspective (Pereiro et al., 2012), as Indigenous tourism. Unusually, in this case, it is the Indigenous people themselves who control the major part of tourist resources, and who try to manage the majority of tourist benefits with a view to avoiding losses. In recent years, the inflow of tourists to Guna Yala has increased considerably, and the Gunas have shown themselves well able to take advantage of that trend. According to GGC data, in the year ending 31 October 2005, 19,698 tourists visited Guna Yala, rising to 20,742 in the same period of 2005-2006. Nowadays, about 100,000 tourists annually visit the region, according to the GGC (Pereiro et al., 2012). From our observations, they arrive by cruise liner (between November and May), mini cruise ships, luxury yachts, sailing boats, light aircraft or off-road vehicles, staying in the 50 or more small hotels and Guna tourist cabins that have been created in the region.

Those hotels and huts can be classified into (1) small traditional Guna hotels whose prices range from US\$10 to US\$80 per person per night; (2) small Guna hotels with rooms priced at 
US\$80-US\$240; and (3) backpacker accommodation with families. The agents for these types of accommodation are Guna families, companies or communities, and the majority of agents boast a university education. The majority of visitors are Americans, followed by Europeans, Latin Americans and Asians. That one of the Guna hotels has received tourists of 49 different nationalities gives an indication of the diversity of tourists visiting the area. The Gunas created a fiscal system for tourism control, according to which all non-Guna visitors arriving in the region must pay a US\$2 comarca tax. In addition to this tax, each cruise liner that docks is charged US\$500 for anchorage, and sailing boats pay a fee of US\$20 for a stay of up to a month in Guna Yala's waters. Apart from comarca taxes, local communities also levy local taxes on the use of their airstrips, harbours or for organized visits.

Tourism is nowadays one of the principal financial sources of the GGC and it is an expanding sector, a fact of which the Gunas are well aware, and that strengthens their commitment to this activity. Manifold opinions on tourism development persist within the comarca, with the major differentiating factor being the benefits each community derives from tourism. The communities of the Gardi area, located close to the road and the harbours that have welcomed cruise liners for over eight decades, are definitely in favour of the recent increased inflow of visitors. For the inhabitants of that area, tourism is a fundamental economic resource. Thanks to the sale of handicrafts, especially "molas" - a colourful textile handicraft - to some degree they have joined the ranks of Panama's consumer society and ensured that some of their children receive a university education. In addition to selling handicrafts and providing services, the 28 communities of the Gardi area offer a wide choice of hotels, many of which have existed there for years and all of which are managed exclusively by Gunas. Nevertheless, in the eastern part of the comarca, which consists of 21 communities, tourism is a somewhat less important activity. The area has not shared the same history of intensive contact with travellers and tourists, for it has a coastline that is conducive to the arrival of cruise liners or short tours, and its hotels are poorly developed.

The obstacles to the development of quality tourism usually identified by the Indigenous business sectors include the lack of training on the part of the inhabitants of the comarca for rendering services, inadequate food supply, malfunctioning or entirely absent basic public services, problems associated with waste management and, in some cases, difficulty in accessing external funds (mortgages or loans from public institutions). Despite these difficulties, the Guna hotel establishments are the only ones that exist in the comarca, each receiving a minimum of 100 and a maximum of 2000 tourists a year.

At present, two kinds of business threaten the maintenance of Guna political control over their tourism: (1) the hotels and cabins that have been built just across the border of the Guna Yala comarca to develop Guna-style tourism without infringing Guna regulations; and (2) small vessels (sailing boats, yachts and catamarans) that charge tourists to be transported to beaches and other attractions. Although sailors plying their trade on the shores of the comarca are prohibited from engaging in any type of "tourist business" in Guna territory, controlling Guna Yala's extensive coastline is no easy task for the Indigenous authorities, and many infractions escape detection. Despite over 50 years of political autonomy, the Guna territory, with its myriad islets, white sand beaches and crystal clear waters, is still coveted by numerous foreign investors.

The Gunas' reaction to this situation has been calm and serene; in 2007, the GGC passed new laws to regulate tourism activity in Guna Yala (see http://www.congresogeneralkuna.org/reglas_turismo_ kuna\%20yala.htm) and established a Secretariat for Tourism Affairs with the objective of strengthening the fundamental law and regulating tourism activities carried out by the Gunas themselves. In March 2008, the GGC's first tourism secretary, Enrique Inatoy, took up his post with the mission of organizing, controlling and promoting the region's tourism. A priority in the new regulations was that "discourtesy to the Guna people and their natural resources" was not to be allowed, and Guna rules, sacred sites and the communal places for rituals and meetings - such as the Onmaked Nega and the Inna Nega - were to be treated with due respect. A number of further proscriptions were instituted: the taking of photographs or recordings of sacred sites and rituals without a license issued by the local authorities; the throwing of coins, food or other objects to Guna people; the 
consumption and carrying of drugs; the possession of firearms; the wearing of swimsuits inside Guna communities; and nudism. To protect marine resources, scuba diving has been banned and, to preserve the environment, the use of many non-biodegradable materials is mandatory and the dropping of litter or dumping of rubbish in public places is prohibited. Food that can be bought in Guna Yala cannot be brought in from outside the comarca. Furthermore, the new rules allow no non-Guna to set up tourist projects in Guna Yala, with Guna initiatives becoming subject to GGC authorization.

The future challenges of Guna tourism are manifold, but in our work we heard many Guna voices highlighting what they consider the key aims:

(1) the correction of negative environmental impacts (in particular, the problem of waste);

(2) the introduction of tourism education at the community level;

(3) improved coordination of the tourist offer;

(4) better political control of tourism resources and products;

(5) greater community focus in the distribution of tourism's benefits;

(6) a redefinition and renovation of Guna culture and ethnicity; and

(7) improved dialogue with the Panamanian state aimed at increasing Guna welfare.

Tourism development in Guna Yala is going through a crucial phase. The key to creating a self-sufficient and more responsible model resides in the consolidation of the financial, political, economic and institutional dimensions of Guna society and the external agents that interact with it, be they tourists or foreign governments. In our view, all external stakeholders should see that it is in their interests to collectively support and strengthen the tourism efforts currently under way, giving due consideration and importance to the social and community structure of Guna society. It should be remembered that, for the Gunas, tourism is little more than a means to an end: the maintenance of control over their territory and their cultural identities.

Besides, Indigenous Guna tourism provides a good example of tourism that has been constructed by the community rather than a community that has been constructed (or deconstructed) by tourism. From this point of view, the Guna case demonstrates the value of local organization and communitarian structures in the empowerment of those developing tourist initiatives (Nielsen \& Wilson, 2012).

\section{Conclusions}

It can be argued that three major conclusions can be drawn on the basis of anthropological research on the effects of tourism and tourists on the receiving communities: (1) tourism is the most important (and sometimes the only) driving force for social and cultural changes; (2) typically, receiving communities do not take an active part in tourism development; (3) as an external force, tourism imposes a heavy acculturating effect on the host community.

However, over the last 20 years, little by little the anthropology of tourism has been changing its vision, affirming that tourism is neither the only nor the most important driving force in many cases (Barreto, 2007; Pereiro, 2015; Santana, 1997). Continuing urbanization processes, modernization, national and international migration trends, and the expansion of digital media have been identified as other significant forces driving cultural change. It is important to note that the impacts on the local population from tourism are difficult to separate from the social forces associated with broader processes of modernization and urbanization.

Moreover, tourism does not always develop from the outside to the inside, but often the other way round, as the empirical reality studied by ethnographers usually shows. That is to say that the relationship between the local and the global is not a one-way street: the active participation of Indigenous groups and communities in tourism development can even entail forms of resistance, reflexive adaptation and proactive initiatives. 
Confronted with the existing models of acculturation (Smith, 1977), of the causality behind local impacts, and of external-internal relationships, some anthropologists, such as Barreto (2007), have proposed new models reflecting the importance of such concepts as reflexivity, dialogism, cosmopolitanism, cultural hybridism and the ethical limits of acceptable change. Noel Salazar also seems to adopt this perspective when he argues that "we must not forget that tourism is only one of various global flows that have enough influence to affect the attitudes and values of people in all societies in a significant way. Others include the globalised mass media, education and urbanization" (2006, p. 118).

The anthropology of tourism has contributed in a substantial way to the analysis and elucidation of tourism's impact on Indigenous communities. A review of the theoretical currents underpinning the analysis of Indigenous tourism clearly demonstrates that, for too long, the concept remained imprecise, ambiguous and polysemous, having multiple meanings. As it is closely related to concepts such as ethnic tourism, ethnotourism, ethno-eco-tourism and aboriginal tourism, Indigenous tourism should be understood not only as another type of tourism, but also as a new way of travelling, and it should play a crucial role in the relation between tourism and poverty reduction strategies. Furthermore, not only the diversity but also the explanatory capacity of international research on Indigenous tourism can be enriched by paying more attention to the Latin American context.

The optimistic, critical and adaptive visions of Indigenous tourism in Latin America presented here basically coincide with the first platforms for tourism analysis proposed by Jafari $(2001,2005)$. The first vision rests on the empowerment of Indigenous groups, but sheds light only on the positive aspect of tourism development. The second view warns of the negative impact of tourism on Latin American Indigenous communities by arguing that leakage effects leave negligible or even negative benefits for the native hosts - a view that tends to neglect or underestimate the proactivity and resistance of Indigenous communities. Focusing on this "other side of the coin" has forced anthropologists of a more critical persuasion to plead for the establishment of alternative forms of Indigenous tourism (e.g. responsible, ethical, fair, community-based) that go beyond mere window-dressing or a superficial marketing strategy or re-branding exercise.

This third vision is inspired by a desire to overcome the dichotomy created by its predecessors by constantly and systematically evaluating both the positive and negative effects of tourism on receiving communities according to the specificities of the contexts, justifications offered and discourses involved, focusing in particular on the creative adaptations made by Indigenous groups, on the form and degree of community participation, and on the self-management of the natural and cultural resources so coveted by the predatory forms of tourism - in sum, by centring their analyses on tourism development processes that aim to incorporate the principles of sustainability and responsibility, including the right of Indigenous peoples to say "no" to tourism.

Our longitudinal fieldwork research with the Guna people of Panama has made us acutely aware of the importance of allowing Indigenous people to control their own involvement in the tourism development, as well as to control their cultural and natural resources so as to develop a more responsible Indigenous tourism. Moreover, our reflections here not only demonstrate the diversity and changing nature of Indigenous tourism in Latin America, but also assesses the sustainability of an alternative Indigenous tourism project and provides insights into how they may provide benefits to marginalized communities, minimize negative impacts, and yet still provide a distinctive visitor experience in line with emerging expectations of responsible travel. Finally, our evaluation of the Guna tourism model concludes that this form of community-based tourism fosters a more sustainable travel experience both in terms of the visitor and the Indigenous host community. This case study also underlines how essential it is that Indigenous groups exert political control over their cultural and natural resources and that they are prepared by a period of social learning during which they can develop their own tourism through a transformative experience and the construction of meaningful connections with people, places, culture, food, heritage and the environment. 


\section{Acknowledgments}

This research is supported by the FEDER component of the European Structural and Investment Funds, via the Operational Programme for Competitiveness and Internationalization (COMPETE 2020) (Project No. 006971 [UID/SOC/04011]), and by national funds provided by the FCT (the Portuguese Foundation for Science and Technology) through project UID/SOC/04011/2013. I am grateful to Professor Chris Gerry (CETRAD, UTAD, Portugal) and the anonymous reviewers of the first version of this paper for their important contributions to the final version, which also benefited from Chris Gerry's revision of the English. Also, I am very grateful to Cebaldo de León, various Guna authorities in Panama, the Guna people and my many Panamanian colleagues and friends, for facilitating the research, and for their hospitality, support and friendly collaboration over the course of the various phases of this longitudinal project.

\section{Disclosure statement}

No potential conflict of interest was reported by the author.

\section{Funding}

This research is supported by the FEDER component of the European Structural and Investment Funds, via the Operational Programme for Competitiveness and Internationalization (COMPETE 2020) (Project No. 006971 [UID/SOC/04011]), and by national funds provided by the FCT (the Portuguese Foundation for Science and Technology) through project UID/SOC/04011/2013.

\section{Notes on contributor}

Xerardo Pereiro is a doctor of Social Anthropology and doctor in Tourism specializing in cultural tourism. His fields of research are the anthropology of tourism, Indigenous tourism in Latin America, agritourism and rural tourism, also border tourism. He is an assistant teacher in the University of Trás-os-Montes and Alto Douro (Portugal) and a member of CETRAD (Research Centre for Transdisciplinary Studies - www.cetrad.info).

\section{References}

Arnaizburne, S.M. (1996). Desarrollo turístico y medioambiente en el Caribe Continental [Tourism and the environment: Development in the Continental Caribbean]. Estudios y Perspectivas en Turismo, 5(2), 259-286.

Barretto, M. (2005). Turismo étnico y tradiciones inventadas [Ethnic tourism and invented traditions]. In A. Santana \& L.L. Prats (Eds.), El encuentro del turismo con el patrimonio cultural: Concepciones teóricas y modelos de aplicación (pp. 39-56). Sevilla: FAAEE- Fundación El Monte.

Barreto, M. (2007). Turismo y Cultura. Relaciones, contradicciones y expectativas [Tourism and culture: Relationships, contradictions and expectations]. La Laguna: Pasos. Retrieved 9 May 2016 from http://www.pasosonline.org

Barth, F. (1969). Ethnic groups and boundaries. London: Allen and Unwin.

Barth, F. (2003). Temáticas Permanente e Emergentes na Análise da Etnicidade [Current and emerging themes in ethnic analysis]. In H. Vermeulen \& C. Govers (Eds.), Antropologia da Etnicidade. Para Além de "Ethnic Groups and Boundaries" (pp. 19-44). Lisboa: Fim de Século.

Blangy, S. (1999). O despegue do ecoturismo [The takeoff of ecoturism]. O Correo da Unesco, Aug-Sept, 32-33.

Bricker, K.S. (2001). Ecotourism development in the rural highlands of Fiji. In D. Harrison (Ed.), Tourism and the less developed world: Issues and case studies (pp. 235-249). Wallingford: CABI Publishing.

Bruner, E.M. (1995). The ethnographer/tourist in Indonesia. In M.F. Lanfant, J.B. Allcock \& E.M. Bruner (Eds.), International tourism. Identity and change (pp. 224-241). London: Sage.

Butler, R., \& Hinch, T. (Ed.). (1996). Tourism and indigenous peoples. London: Thompson.

Camargo, B.A., \& Jamal, T. (2014). Sustainable tourism, justice and an ethic of care: Toward the just destination. Journal of Sustainable Tourism, 22(1), 11-30.

Canadian Tourism Commission (Ed.). (1997). Aboriginal tourism: A bibliography. Toronto: Tourism Reference and Documentation Centre. Retrieved 14 November 2015 from http://www.canadatourism.com

Cañada, E. (2010). Impactos del turismo en los países del sur y turismo rural comunitario. Material de apoyo [Impacts of tourism on rural communities: Support material]. Madrid: Foro Turismo Responsable.

Canestrini, D. (2009). No disparen contra el turista. Un análisis del turismo como colonización [Do not shoot the tourist. An analysis of tourism as colonization]. Barcelona: Ediciones Bellaterra.

Cavaco, C. (2011). Turismo Rural Comunitário (TRC) e desenvolvimento local na América Latina - Um olhar europeu [Tourism in rural communities and local involvement in Latin America: A European viewpoint. In M. De Souza \& I. 
Elesbão (Eds.), Turismo Rural. Iniciativas e Inovações (pp. 145-213). Porto Alegre: Universidade Federal de Rio Grande do Sul.

Chambers, E. (2000). Native tours. The anthropology of travel and tourism. Prospect Heights, IL: Waveland Press.

Chambers, E. (2005). Can the anthropology of tourism make us better travellers? In T. Wallace (Ed.), Tourism and applied anthropologists. Linking theory and practice (pp. 27-59). Berkeley: University of California Press.

Chang-Vargas, G. (2013). Turismo étnico: Sus trampas en algunos casos de comunidades indígenas de Costa Rica [Ethnic tourism: Pitfalls for Indigenous communities in Costa Rica]. In J. Osorio \& E. Rozo (Eds.), Turismo y cultura. Retos y perspectivas en América Latina (pp. 391-422). Bogotá: Universidad Externado de Colombia.

Chaves, R. (2012). El turismo étnico em comunidades indígenas do Brasil. A reserva indígena da Jaqueira e o parque indígena do Xingu [Ethnic tourism in Indigenous communities in Brazil: An Indian reserve in Xingu Indigenous Park]. In B. Pérez Galán \& R. Asensio (Eds.), ¿El turismo es cosa de pobres? Patrimonio cultural, pueblos indígenas y nuevas formas de turismo en América Latina (pp. 115-129). La Laguna: Pasos.

Chernela, J.M. (2011). Barrier natural and unnatural: Islamiento as a central metaphor in Kuna Ecotourism. Bulletin of Latin American Research, 30(1), 35-49.

Colvin, J.G. (1994). Capirona: A model of indigenous ecotourism. Journal of Sustainable Tourism, 2(3), $174-177$.

Comaroff, J., \& Comaroff, J. (1992). Ethnography and the historical imagination. Boulder, CO: Westview Press.

Comaroff, J., \& Comaroff, J. (2009). Ethnicity, Inc. Chicago, IL: The University of Chicago Press.

Coronado, G. (2014). Selling culture? Between commoditisation and cultural control in Indigenous alternative tourism. Pasos-Revista de Turismo y Patrimonio Cultural, 12(14), 11-28.

De Burlo, C.R. (2000). Indigenous. In J. Jafari (Ed.), Encyclopedia of tourism (pp. 303-304). London: Routledge.

Espinosa, M. (2010). Turismo Comunitario en Saraguro - Ecuador [Community tourism in Saraguro, Ecuador]. In Sodepaz (Ed.), Turismo y Desarrollo: Experiencias desde la Cooperación Internacional (pp. 65-117). Madrid: Sodepaz.

Falconí, F., \& Ponce, J. (2007). Desarrollo social y económico de la Amazonía Ecuatoriana basado en el ecoturismo: emprendimientos populares como alternativa a un desarrollo excluyente [Social and economic development in the Ecuadorian Amazon based on ecotourism: Local enterprises as an alternative to an exclusive development]. Palma de Mallorca: Fundació Càtedra Iberoamericana - Universidad de las Islas Baleares. Retrieved 14 November 2015 from http://www.uib.es/catedra-iberoamericana

Gascón, J. (2009). El turismo en la cooperación Internacional. De las brigadas Internacionalistas al turismo solidario [Tourism and international cooperation. The internationalist brigades of community tourism] Barcelona: Icaria.

Gascón, J. (2013). The limitations of community-based tourism as an instrument of development cooperation: The value of the social vocation of the territory concept. Journal of Sustainable Tourism, 21(5), 716-731.

Gascón, J., \& Cañada, E. (2005). Viajar a todo tren [All train travel]. Barcelona: Icaria.

Gascón Gutiérrez, J. (2005). Gringos como en sueños. Diferenciación y conflicto campesino en el sur andino peruano ante el desarrollo del turismo [Peasant differentiation and conflict in the southern Peruvian Andes to the development of tourism]. Lima: Instituto de Estudios Peruanos.

Getino, O. (1991). Turismo y Desarrollo en América Latina [Tourism and development in Latin America]. México: Editorial Limusa.

Gibson, D., Pratt, S., \& Movono, A. (2012). Tribe tourism: A case study of the Tribewanted Project on Vorovoro, Fiji. In S. Fullagar, K. Markwell \& E. Wilson (Eds.), Slow tourism: Experiences and mobilities (pp. 185-200). Bristol: Channel View.

Goodwin, H. (2011). Taking responsibility for tourism. Oxford: Goodfellow Publishers.

Grünewald, R. (2001a). Turismo e o "resgate" da cultura Pataxó [Tourism and the "rescue" of Pataxó culture]. In A. Jr. Banducci \& M. Barretto (Eds.), Turismo e Identidade Local: Uma Visão Antropológica (pp. 127-148). Campinas: Papirus.

Grünewald, R. (2001b). Os índios do descobrimento. Tradição e turismo [The Indians of discovery. Tradition and tourism]. Rio de Janeiro: Contra Capa Livraria.

Grünewald, R. (2003). Turismo e etnicidade [Tourism and ethnicity]. Horizontes antropológicos, 20, 141-159.

Harron, S., \& Weiler, B. (1992). Review. Ethnic tourism. In B. Weiler \& C.M. Hall (Eds.), Special interest tourism (pp. 83-92). London: Bellhaven.

Hernández Ramírez, J. (2006). Producción de singularidades y mercado global. El estudio antropológico del turismo [Production requirements and the global market: The anthropological study of tourism. Boletín Antropológico, 66, 21-50.

Howe, J. (1998). A people who would not kneel: Panama, the United States, and the San Blas Kuna. Washington, DC: Smithsonian Institution Press.

Howe, J. (2009). Chiefs, scribes and ethnographers. Guna culture from inside and out. Austin: The University of Texas Press. Ingles, P. (2002). Welcome to my village: Hosting tourists in the Peruvian Amazon. Tourism Recreation Research, 27(1), $53-60$.

Jafari, J. (2001). Toward an Ethics platform for tourism. Annals of Tourism Research, 32(4), 962-984.

Jafari, J. (2005). El turismo como disciplina científica [Tourism as a scientific discipline]. Política y Sociedad, 42(1), 39-56.

Johnston, A.M. (2006). Is the sacred for sale? Tourism and indigenous peoples. London: Earthscan.

Kirtsoglou, E., \& Theodossopoulos, D. (2004). They are taking our culture away: Tourism and culture commodification in the Garifuna community of Roatan. Critique of Anthropology, 24(2), 135-157.

Kutzner, D., Maher, P.T., \& Wright, P. (2007). Aboriginal tourism: A research bibliography. Prince George: University of Northern British Columbia. Retrieved 16 November 2015 from http://www.unbc.ca/assets/ortm/research/repor t_2007_02_aboriginal_tourism_bibliography.pdf 
Lumsdon, L., \& Swift, J. (2001). Tourism in Latin America. London: Continuum.

Maccanell, D. (1984). Reconstructed ethnicity tourism and cultural identity in third world communities. Annals of Tourism Research, 11(3), 375-391.

Maccannel, D. (1992). Empty meeting grounds. New York, NY: Routledge and Kegan Paul.

Maldonado, C. (2006). Turismo y comunidades indígenas: Impactos, pautas para autoevaluación y códigos de conducta (Documento de trabajo número 79) [Tourism and indigenous communities: Impacts, self-assessment guidelines and codes of conduct] (Working Paper No. 79). Geneva: Oficina Internacional del Trabajo (OIT).

Mastny, L. (2003). Ecoturismo. Nuevos caminos para el turismo internacional [Ecotourism: Pioneering international tourism]. Bilbao: Bakeaz.

Mercer, D. (1995). Native people and tourism: Conflict and compromise. In W.F. Theobald (Ed.), Global tourism - the next decade (pp. 124-145). Oxford: Butterworth-Heinemann.

Morales, G., \& Marías, D. (2007). Turismo en comunidades indígenas [Tourism in Indigenous communities]. Revista Ábaco 2ae época, 54, 123-133.

Moscardo, G., \& Pearce, P.L. (1999). Understanding ethnic tourists. Annals of Tourism Research, 26(2), 416-434.

Mowforth, M., Charlton, C., \& Munt, I. (2008). Tourism and responsibility: Perspectives from Latin American and the Caribbean. London: Routledge.

Nash, D. (1977). Tourism as a form of imperialism. In V.L. Smith (Ed.), Hosts and guests: The anthropology of tourism (pp. 33-47). Philadelphia: University of Pennsylvania Press.

Nielsen, N., \& Wilson, E. (2012). From invisible to indigenous-driven: A critical typology of research in indigenous tourism. Journal of Hospitality and Tourism Management, 19(1), 67-75.

Notzke, C. (2006). The stranger, the native and the land: Perspectives on Indigenous tourism. Concord: Captus Press.

Osorio, J., \& Rozo, E. (Eds.). (2013). Turismo y cultura. Retos y perspectivas en América Latina [Tourism and culture. Challenges and perspectives in Latin America]. Bogotá: Universidad Externado de Colombia.

Panosso Netto, A. (2011). Filosofia do turismo. Teoria e epistemologia [The philosophy of tourism: Theory and epistemology]. São Paulo: Aleph.

Pereiro, X. (2009). Turismo cultural. Uma visão antropológica [Cultural tourism: An anthropological viewpoint]. La Laguna: Pasos online.

Pereiro, X. (2010). Ethnographic research on cultural tourism: An anthropological view. In G. Richards \& W. Munsters, (Eds.), Cultural tourism research methods (pp. 173-187). Wallingford: CABI.

Pereiro, X. (2013). Los efectos del turismo en las culturas indígenas de América Latin [The effects of tourism on indigenous cultures in Latin America]. Revista Española de Antropología Americana, 43(1), 155-174.

Pereiro, X. (2015). Texto de abertura: Pelo(s) Trilho(s) dos Turismo(s) Indígena(s) [Opening text: By the tracks of Indigenous tourism]. Agália - Revista de Estudos na Cultura, 9-34. Special volume 2015 about tourism in indigenous territories.

Pereiro, X., \& De León, C. (2007). Los impactos del turismo en Kuna Yala. Turismo y cultura entre los kuna de Panamá [The Impacts of Tourism on the Lands of the Kuna: Tourism and cultural issues]. Madrid: Ramón Areces.

Pereiro, X., \& De León, C. (2014). Turismo e performances culturais: uma visão antropológica do turismo indígena guna (Panamá) [Tourism and cultural performances: An anthropological view of indigenous Guna tourism (Panama)]. In P. Godinho (Ed.), Antropologia e Performance. Agir, Atuar, Exibir (pp. 311-326). Castro Verde: 100Luz Editora.

Pereiro, X., Martínez, M., Ventocilla, J., De León, C., \& Del Valle, Y. (2012). Los turistores kunas. Antropología del turismo étnico en Panamá [Kuna tourism: The anthropology of ethnic tourism in Panama]. Mallorca: University of the Balearic Islands.

Pérez Galán, B. (2011). Nuevas y viejas narrativas turísticas sobre la cultura indígena en los Andes [New and old narratives on tourism on indigenous culture in the Andes]. In L.L. Prats \& A. Santana (Eds.), Turismo y patrimonio. Entramados narrativos (pp. 27-48). La Laguna: Pasos. Retrieved 8 May 2016 from http://www.pasosonline.org

Phillimore, J., \& Goodson, I. (Eds.) (2004). Qualitative research in tourism. Ontologies, epistemologies and methodologies. London: Routledge.

Pi-Sunyer, O., Brooke, T.R., \& Daltabuit, M. (2001). Tourism on the Maya periphery. In V.L. Smith \& M. Brent (Eds.), Hosts and guests revisited: Tourism issues of the 21st century (pp. 122-140). New York, NY: Cognizant.

Richards, G. (1996). Introduction: Culture and tourism in Europe. In G. Richards (Ed.), Cultural tourism in Europe (pp. 3-17). Oxon: $\mathrm{CABI}$.

Ritchie, B.W., Burns, P., \& Palmer, C. (2005). Tourism research methods. Integrating theory with practice. Wallingford: CABI.

Rodríguez Miranda, R. (Ed.). (2011). Construyendo resistencias. Experiencias de turismo local [Building resistance. Experiences of local tourism]. Madrid: Foro Turismo Responsable.

Rosaldo, R. (1989). Cultura y Verdad. Nueva propuesta de analisis social [Culture and Truth: The remaking of social analysis]. Mexico City: Grijalbo.

Ruiz, E., Hernández,, M., Coca, A., Cantero, P., \& Del Campo, A. (2008). Turismo Comunitario en Ecuador. Comprendiendo el community-based tourism desde la comunidad [Community tourism in Ecuador. Understanding community-based tourism]. PASOS - Revista de Turismo y Patrimonio Cultural, 6(3), 399-418.

Ryan, C. (2005a). Introduction. Tourist-host nexus. Research considerations. In C. Ryan \& M. Aicken (Eds.), Indigenous tourism: The commodification and management of culture (pp. 1-15). Oxford: Elsevier. 
Ryan, C. (2005b). Who manages indigenous cultural tourism product - aspiration and legitimation. In C. Ryan \& M. Aicken (Eds.), Indigenous tourism: The commodification and management of culture (pp. 69-74). Oxford: Elsevier.

Ryan, C., \& Aicken M. (Eds.). (2005). Indigenous tourism: The commodification and management of culture. Oxford: Elsevier.

Ryan, C., \& Huyton, J. (2005). Balanda tourists and aboriginal people. In Ch. Ryan \& M. Aicken (Eds.), Indigenous tourism: The commodification and management of culture (pp. 51-68). Oxford: Elsevier.

Saarinen, J. (2013). Indigenous tourism and the challenge of sustainability. In M. Smith \& G. Richards (Eds.), The Routledge handbook of cultural tourism (pp. 220-226). London: Routledge.

Salazar, N.B. (2006). Antropología del turismo en países en desarrollo: análisis crítico de las culturas, poderes e identidades generados por el turismo [An anthropology of tourism in developing countries: Critical analysis of cultures, powers and identities generated by tourism]. Tabula Rasa, 5, 99-128.

Santana, A. (1997). Antropología y Turismo. ¿Nuevas Hordas, Viejas Culturas? [Anthropology and tourism. New Hordes, old cultures?]. Barcelona: Ariel.

Smith, V. (1977). Hosts and guests: The anthropology of tourism. Philadelphia: University of Pennsylvania Press.

Smith, V.L. (1996). Indigenous tourism: The four Hs. In R. Butler \& T. Hinch (Eds.), Tourism and Indigenous peoples (pp. 283-307). London: Thomson.

Smith, L.T. (1999). Decolonizing methodologies. Research and indigenous peoples. London: Zed Books.

Smith, V.L. \& Eadington, W.R. (Eds.). (1992). Tourism alternatives: Potentials and problems in the development of tourism. Philadelphia: University of Pennsylvania Press.

Snow, S.G. (2001). The Kuna general congress and the statute on tourism. Cultural Survival Quarterly, 24(4). Retrieved 11 November 2015 from http://www.culturalsurvival.org

Simpson, M.C. (2008). Community benefit tourism initiatives - a conceptual oxymoron? Tourism Management, 29(1), $1-18$.

Thomson-Carr, A. (2013). Mãori tourism. A case study of managing Indigenous cultural values. In M. Smith \& G. Richards (Eds.), The Routledge handbook of cultural tourism (pp. 227-235). London: Routledge.

UNWTO. (2003). Turismo internacional: uma perspectiva global [International tourism: A global perspective]. Porto Alegre: Bookman.

Van Den Berghe, P. (1980). Tourism as ethnic relations: A case study of Cuzco, Peru. Ethnic and Racial Studies, 3(4), 375-391.

Van den Berghe, P. (1994a). The quest for the other: Ethnic tourism in San Cristobal México. Seattle: University of Washington Press.

Van den Berghe, P. (1994b). Marketing Mayas: Ethnic tourism promotion in Mexico. Annals of Tourism Research, 22(3), $568-588$.

Vermeulen, H., \& Govers, C. (Eds.). (2003). Antropologia da Etnicidade. Para Além de Ethnic Groups and Boundaries [An anthropology of race: Ethnic groups and boundaries]. Lisboa: Fim de Século.

Vigna, A. (2006, July). Los "falsarios" del ecoturismo: Grandes proyectos privados en América Central [The "forgers" of ecotourism: Large private projects in Central America]. Le Monde Diplomatique (Spanish edition), pp. 17-19.

Volkman, T.A. (1990). Visions and revisions: Toraja culture and the tourist Gaze. American Ethnologist, 17(1), $91-110$.

Weaver, D. (2010). Indigenous tourism stages and their implications for sustainability. Journal of Sustainable Tourism, 18 (1), 43-60.

Wilson, T.D. (2008). Introduction: The impacts of tourism in Latin America. Latin American Perspectives, 160(35), 3-20.

Yang, L., \& Wall, G. (2009). Ethnic tourism: A framework and an application. Tourism Management, 30, 559-570.

Zeppel, H. (1999). Aboriginal tourism in Australia: A research bibliography update. Work in progress - Report Series. Cooperative Research Centre for Sustainable Tourism. Retrieved 9 November 2015 from http://www.crctourism.com.au/ WMS/Upload/Resources/bookshop/Update_AboriginalTourism.PDF

Zeppel, H. (2007). Indigenous ecotourism: Conservation and resources rights. In J. Higham (Ed.), Critical issues in ecotourism. Understanding a complex tourism phenomenon (pp. 308-348). Oxford: Elsevier.

Zoettl, P.A. (2010). Capa de Índio [Indians in disguise]. Anthropological documentary on DVD. Lisboa: Peter Antón Zoettl.

Zorn, E., \& Farthing, L.C. (2007). Communitarian tourism. Hosts and mediators in Peru. Annals of Tourism Research, 34(3), $673-689$. 